\title{
ANALISIS KESTABILAN DAN KONTROL OPTIMAL MODEL LESLIE-GOWER FUNGSI RESPON HOLLING III DENGAN PEMANENAN PADA POPULASI PREDATOR DAN PREY
}

\author{
Febriyanti Himmatul Ulya ${ }^{1)}$, Syamsuddin Toaha ${ }^{2)}$, Kasbawati ${ }^{3)}$
}

\begin{abstract}
This article modified the leslie-gower model on harvesting with predator and prey population. This study aims at construct a modification of leslie-gower model with holing III response function. In addition, there is an effort harvesting in predator and prey population, analyzing an equilibrium point, finding bionomic equilibrium and the condition where the present value is maximum from net income by controlling harvesting in both populations. In the modified leslie-gower model there is an equilibrium point $T_{2}\left(x_{2}^{*}, y_{2}^{*}\right)$ which is asymptotically stable and when there have harvesting, the equilibrium point $H_{2}\left(x_{4}^{*}, y_{4}^{*}\right)$ is also asymptotically stable. Bionomic equilibrium from harvesting on the modified leslie-gower model $P\left(x_{\infty}, y_{\infty}, E_{\infty}\right)$ is maximizing the profit function $\pi$ of harvesting on a model with the maximum pontryagin principle resulting an optimal equilibrium $\left(x_{\delta}, y_{\delta}, E_{\delta}\right)$ affected by instantaneous rate of discount $\delta$.
\end{abstract}

Keywords: leslie-gower, holling III, bionomic equilibrium, maximum pontryagin policy

\begin{abstract}
Abstrak
Pada artikel ini penelitian yang dilakukan adalah memodifikasi model leslie-gower dengan pemanenan pada populasi predator dan prey. Penelitian ini bertujuan merekonstruksi modifikasi model leslie-gower dengan menggunakan fungsi respon holling III serta terdapat upaya pemanenan pada populasi predator dan prey, menganalisis titik kesetimbangan, menentukan kesetimbangan bionomik dan kondisi yang dapat memaksimumkan nilai present value dari pada pendapatan bersih dengan mengontrol pemanenan pada kedua populasi. Pada modifikasi model leslie-gower terdapat sebuah titik kesetimbangan $T_{2}\left(x_{2}^{*}, y_{2}^{*}\right)$ bersifat stabil asimtotik dan saat terdapat pemanenan titik kesetimbangan $H_{2}\left(x_{4}^{*}, y_{4}^{*}\right)$ bersifat stabil asimtotik. Kesetimbangan bionomik dari pemanenan yang dilakukan pada modifikasi model leslie-gower $P\left(x_{\infty}, y_{\infty}, E_{\infty}\right)$, memaksimalkan fungsi keuntungan $\pi$ dari pemanenan yang dilakukan pada model dengan prinsip maksimum pontryagin menghasilkan kesetimbangan optimal $\left(x_{\delta}, y_{\delta}, E_{\delta}\right)$ yang dipengaruhi diskonto $\delta$.
\end{abstract}

Kata kunci: leslie-gower, holling III, kesetimbangan bionomik, prinsip maksimum pontryagin.

${ }^{122) 3)}$ Universitas Hasanuddin, Fakultas Matematika dan Ilmu Pengetahuan Alam, Jalan Perintis Kemerdekaan, Makassar.

${ }^{1)}$ febrii8293@gmail.com, ${ }^{2)}$ syamsuddint@yahoo.com, ${ }^{3)}$ kasbawati@gmail.com 


\section{Febriyanti Himmatul Ulya, Syamsuddin Toaha, Kasbawati}

\section{Pendahuluan}

Banyak model predator-prey yang digunakan untuk menggambarkan interaksi predator-prey antara lain model lotka-volterra. Gause (1934) mengalami kegagalan untuk menggambarkan laju pertumbuhan kedua populasi yang diperolehnya dengan model lotka-volterra dan leslie (1948) dapat memperoleh model yang mereprsentasikan data pertumbuhan yang diperoleh oleh Gause (Berryman, 1992). Dalam memangsa, predator menghabiskan waktu dalam mencari dan berinteraksi dengan prey dan predator memiliki kapasitas terbatas dalam memangsa. Jumlah populasi prey mempengaruhi respon predator dalam memangsa disebut fungsi respon predasi. Terdapat tiga tipe fungsi respon yang dikemukakan holling. Fungsi respon holling I terjadi pada predator yang bersifat pasif seperti laba-laba. Fungsi respon holling II terjadi pada predator yang bersifat aktif dan predator membutuhkan waktu dalam mencerna prey, seperti yang dilakukan serigala. Pada fungsi respon holling III, predator akan selektif memilih prey ketika jumlah prey tinggi dan akan mencari alternatif prey memangsa ketika kepadatan prey tersebut rendah.

Populasi predator dan prey dengan nilai ekonomi memiliki kemungkinan untuk dipanen. Laju pertumbuhan predator dan prey yang dipengaruhi oleh banyaknya jumlah populasi yang dipanen. Jika hasil pemanenan yang dilakukan memperoleh keuntungan, pemanen cenderung melakukan pemanenan sebanyak-banyaknya agar mendapatkan keuntungan yang maksimal. Pemanenan populasi yang terus menerus tanpa mempertimbangan jumlah populasi dapat mengakibatkan kelangkaan atau kepunahan dan bahkan tidak dapat dilakukan pemananen secara berkelanjutan.

Sharma, dkk (2014 menganalisis dinamika pemanenan kedua spesies tersebut. Model laju pertumbuhan populasi disusun berdasarkan perilaku interaksi antara phytoplankton dan zooplankton. Sharma, dkk menggunakan prinsip maksimum pontryagin untuk menentukan kebijakan optimal untuk hasil maksimum dan pemanenan dapat dilakukan secara berkelanjutan. Penelitian lain tentang model ekologi juga dilakukan oleh Yue (2016). Yue membahas dinamika model leslie-gower dengan fungsi respon holling II.

\section{Model Matematika}

Leslie (1948) memperkenalkan model predator-prey dengan kompetisi intraspesifik, sehingga diperoleh model sebagai berikut:

$$
\begin{aligned}
& \frac{d x}{d t}=r_{1} x-b x^{2}-a_{1} x y, \\
& \frac{d y}{d t}=r_{2} y-\frac{a_{2} y^{2}}{x}
\end{aligned}
$$

Model leslie-gower memiliki asumsi bahwa carrying capacity predator dipengaruhi oleh kepadatan prey, yaitu

$$
\frac{d y}{d t}=r_{2} y-\frac{y^{2}}{C}
$$

dengan $C=l x$ sebagai carrying capacity dari predator yang sebanding dengan jumlah prey dan $l$ merupakan koefisien konversi prey menjadi predator, sehingga persamaan (2) menjadi:

$$
\frac{d y}{d t}=r_{2} y-\frac{y^{2}}{l x}
$$

dan bentuk $\frac{y}{l x}$ diasumsikan sebagai hilangnya predator karena kelangkaan prey utama. Kelangkaan pada prey dapat merangsang predator untuk mencari alternatif prey lain, namun 


\section{Febriyanti Himmatul Ulya, Syamsuddin Toaha, Kasbawati}

pertumbuhannya tetap memiliki batas (carrying capacity), sehingga ditambahkan konstanta positif $d$ karena predator tidak bergantung pada prey tunggal, sehingga menjadi,

$$
\frac{d y}{d t}=r_{2} y-\frac{y^{2}}{l x+d}
$$

dengan $a_{2}=\frac{1}{l}, k_{2}=\frac{d}{l}$ dan fungsi respon holling III sebagai fungsi respon predasi, maka model (1) menjadi,

$$
\begin{aligned}
& \frac{d x}{d t}=r_{1} x-b x^{2}-\frac{a_{1} x^{2} y}{x^{2}+k_{1}}, \\
& \frac{d y}{d t}=r_{2} y-\frac{a_{2} y^{2}}{x+k_{2}}
\end{aligned}
$$

Terdapat upaya pemanenan $E(t)$ terhadap predator dan prey yang memiliki nilai ekonomi, sehingga dilakukan pada kedua populasi tersebut, sehingga diperoleh,

$$
\begin{aligned}
& \frac{d x}{d t}=r_{1} x-q_{1} E x-b x^{2}-\frac{a_{1} x^{2} y}{x^{2}+k_{1}} \\
& \frac{d y}{d t}=r_{2} y-q_{2} E y-\frac{a_{2} y^{2}}{x+k_{2}}
\end{aligned}
$$

Parameter $r_{1}, r_{2}, b, a_{1}, a_{2}, k_{1}$ dan $k_{2}$ bernilai positif dengan $r_{1}$ dan $r_{2}$ merupakan laju pertumbuhan intrinsik dari prey dan predator, $b$ merupakan laju interkasi antar prey, $a_{1}$ Laju pemangsaan dari predator, $a_{2}$ merupakan laju interaksi antar predator, $k_{1}$ adalah half saturation constant dari prey, $k_{2}$ adalah perlindungan terhadap predator oleh lingkungan dan $E$ prmanenan yang dilakukan terhadap predator dan prey. Dari model (5), diperoleh dua titik kesetimbangan non feasible $(0,0),\left(0, \frac{r_{2} k_{2}}{a_{2}}\right)$, sebuah titik kesetimbangan yang bersifat tidak stabil $T_{1}\left(x_{1}^{*}, 0\right)$ dan sebuah titik kesetimbangan yang bersifat stabil asimtotik $T_{2}\left(x_{2}^{*}, y_{2}^{*}\right)$ dengan $r_{1}+r_{2}<2 b x_{2}^{*}+\frac{2 a_{1} x_{2}^{*} y_{2}^{*}}{x_{2}^{* 2}+k_{1}}-\frac{2 a_{1} x_{2}^{* 3} y}{\left(x_{2}^{* 2}+k_{1}\right)^{2}}+\frac{2 a_{2} y}{x_{2}^{*}+k_{2}}$ dan $r_{1}<2 b x+$ $\frac{2 a_{1} x y}{x^{2}+k_{1}}-\frac{2 a_{1} x^{3} y}{\left(x^{2}+k_{1}\right)^{2}}, r_{2}<\frac{2 a_{2} y_{2}^{*}}{x_{2}^{*}+k_{2}}$ atau $r_{1}>2 b x_{2}^{*}+\frac{2 a_{1} x_{2}^{*} y_{2}^{*}}{x_{2}^{* 2}+k_{1}}-\frac{2 a_{1} x_{2}^{* 3} y}{\left(x_{2}^{* 2}+k_{1}\right)^{2}}+\frac{2 a_{2} y}{x_{2}^{*}+k_{2}}, r_{2}>\frac{2 a_{2} y_{2}^{*}}{x_{2}^{*}+k_{2}}$.Pada model (6) erdapat dua titik kesetimbangan non feasible $(0,0),\left(0, \frac{k_{2}\left(r_{2}-q_{2} E\right)}{a_{2}}\right)$, sebuah titik kesetimbangan yang bersifat tidak stabil $H_{1}\left(x_{3}^{*}, 0\right)$ dan sebuah titik kesetimbangan yang bersifat stabil asimtotik dengan $r_{1}+r_{2}<2 b x_{4}^{*}+\frac{2 a_{1} x_{4}^{*} y_{4}^{*}}{x_{4}^{* 2}+k_{1}}-\frac{2 a_{1} x_{4}^{* 3} y_{4}^{*}}{\left(x_{4}^{* 2}+k_{1}\right)^{2}}+\frac{2 a_{2} y_{4}^{*}}{x_{4}^{*}+k_{2}}+q_{1} E+q_{2} E \quad$ dan $\quad r_{1}<\left(2 b x_{4}^{*}+q_{1} E++\frac{2 a_{1} x_{4}^{*} y_{4}^{*}}{x_{4}^{* 2}+k_{1}}-\right.$ $\left.\frac{2 a_{1} x_{4}^{* 3} y_{4}^{*}}{\left(x_{4}^{* 2}+k_{1}\right)^{2}}\right), r_{2}<\frac{2 a_{2} y_{4}^{*}}{x_{4}^{*}+k_{2}}+q_{2} E$ atau $r_{1}>2 b x_{4}^{*}+\frac{4 a_{1} x_{4}^{* 3} y+2 a_{1} k_{1} x_{4}^{* 3} y_{4}^{* 3}}{\left(x_{4}^{* 2}+k_{1}\right)^{2}}+q_{1} E, r_{2}>\frac{2 a_{2} y_{4}^{*}}{x_{4}^{*}+k_{2}}+q_{2} E$.

\section{Kesetimbangan Bionomik}

Kesetimbangan bionomik adalah suatu konsep yang mengintegrasikan kesetimbangan secara biologi dan keseimbangan secara ekonomi. Misalkan terdapat dua populasi yang ditinjau, yaitu $x$ dan $y$. Keseimbangan secara ekologi diperoleh ketika populasi berada pada kondisi $\frac{d x}{d t}=0$ dan $\frac{d y}{d t}=0$. Titik keseimbangan ini diperoleh dengan menyelesaikan sistem persamaan terhadap $x$ dan $y$. Titik kesetimbangan ini menyatakan suatu kondisi dimana kedua populasi dalam keadaan setimbang, yaitu kedua populasi tidak mengalami perubahan karena laju pertumbuhannya nol. Kesetimbangan secara ekonomi dikatakan tercapai ketika pendapatan total $(T R)$ yang diperoleh dari penjualan stok (populasi) yang dipanen sama dengan biaya total $(T C)$ dari usaha yang dilakukan dalam pemanenan populasi 


\section{Febriyanti Himmatul Ulya, Syamsuddin Toaha, Kasbawati}

(Toaha, 2013). Bentuk umum dari pemanenan menggunakan persamaan pemanenan Schaefer (1954) pemanenan dirumuskan (Clark, 2006):

$$
h=q E x
$$

dengan $h$ merupakan laju pemanenan dengan total penerimaan bersih per satuan waktu. Fungsi keuntungan dari usaha pemanenan populasi adalah

$$
\pi=T R-T C
$$

Total pendapatan (TR) diperoleh dari harga perunit biomassa $p$ dikalikan dengan laju pemanenan $h$. Sedangkan untuk total pembiayaan $(T C)$ sebanding dengan biaya pemanenan per unit usaha $C$ dikalikan dengan usaha $E$ yang dirumuskan (Prastiwi, 2012):

$$
\pi=p h-c E
$$

Maka, persamaan fungsi keuntungan dengan pemanenan yang dilakukan pada populasi predator dn prey adalah sebagai berikut:

$$
\pi(E)=\left(p_{1} q_{1} x+p_{2} q_{2} y-C\right) E
$$

dengan $p_{1}$ merupakan harga prey per unit biomassa, $p_{2}$ adalah harga predator per unit biomassa dan $C$ merupakan pembiayaan yang dikeluarkan dalam melakukan pemanenan populasi.

Kesetimbangan bionomik adalah $P_{\infty}=\left(x_{\infty}, y_{\infty}, E_{\infty}\right)$ dengan $x_{\infty}, y_{\infty}, E_{\infty}$ adalah solusi positif dari persamaan berikut:

$$
\begin{aligned}
& \frac{d x}{d t}=r_{1} x-q_{1} E x-b x^{2}-\frac{a_{1} x^{2} y}{x^{2}+k_{1}}=0 \\
& \frac{d y}{d t}=r_{2} y-q_{2} E y-\frac{a_{2} y^{2}}{x+k_{2}}=0 \\
& \pi(E)=\left(p_{1} q_{1} x+p_{2} q_{2} y-C\right) E=0
\end{aligned}
$$

dari persamaan (11) dan (12) diperoleh

$$
E=\frac{1}{q_{1}}\left(r_{1}-b x-\frac{a_{1} x y}{x^{2}+k_{1}}\right)=\frac{1}{q_{2}}\left(r_{2}-\frac{a_{2} y}{x+k_{2}}\right)=0
$$

Jika biaya yang dikeluarkan untuk upaya pemanenan lebih besar dari pendapatan dari penjualan hasil pemanenan $\left(C>p_{1} q_{1} x+p_{2} q_{2} y\right)$, maka fungsi keuntungan akan bernilai negatif dan mengakibatkan pemanenan berhenti dan tidak terdapat kesetimbangan bionomik. Agar terdapat kesetimbangan bionomik, maka diasumsikan bahwa biaya yang dikeluarkan untuk pemanenan lebih kecil dari pendapatan yang diperoleh dari penjualan hasil pemanenan $\left(C<p_{1} q_{1} x+p_{2} q_{2} y\right)$. Melalui persamaan (12) dan (13) diperoleh,

$$
\begin{aligned}
& y_{\infty}=\frac{C-p_{1} q_{1} x_{\infty}}{p_{2} q_{2}} \\
& E_{\infty}=\frac{r_{2}}{q_{2}}-\frac{a_{2}\left(C-p_{1} q_{1} x_{\infty}\right)}{p_{2} q_{2}^{2}\left(x_{\infty}+k_{2}\right)}
\end{aligned}
$$

$$
\begin{aligned}
& \text { dengan } \frac{a_{2} C-k_{2} p_{2} q_{2} r_{2}}{q_{2} p_{2} r_{2}+a_{2} p_{1} q_{1}}<x_{\infty}<\frac{C}{p_{1} q_{1}}, \quad 0<y_{\infty}<-\frac{1}{p_{2} q_{2}}\left(\frac{\left(a_{2} C-k_{2} p_{2} r_{2}\right)\left(p_{1} q_{1}\right)}{\left(q_{2} p_{2} r_{2}+a_{2} p_{1} q_{1}\right)}-C\right) \text { dan }\left(\left(-k_{2} p_{2} q_{2} r_{2}+\right.\right. \\
& \left.C a_{2}\right)\left(-a_{2} p_{1} q_{1}-p_{2} q_{2} r_{2}+\left(k_{2} p_{2} q_{2} r_{2}-C a_{2}+r_{2} p_{2} q_{2} k_{2}-a_{2} C\right)\left(a_{2} p_{1} q_{1}+p_{2} q_{2} r_{2}\right)\right)\left(a_{2} p_{1} q_{1}+\right. \\
& \left.p_{2} q_{2} r_{2}\right) /\left(a_{2} p_{1} q_{1}+p_{2} q_{2} r_{2}\right)\left(k_{2} p_{2} q_{2}\left(a_{2} p_{1} q_{1}+p_{2} q_{2} r_{2}\right)^{2}-\left(-k_{2} p_{2} q_{2} r_{2}+C a_{2} p_{2} q_{2}^{2}<E_{\infty}<\right.\right. \\
& \left(C\left(-a_{2} p_{1} q_{1}-p_{2} q_{2} r_{2}\right)+k_{2} p_{2} q_{2} r_{2} p_{1} q_{1}-C a_{2} p_{1} q_{1}\right) /\left(-k_{2} p_{1} p_{2} q_{1} q_{2}^{2}-C p_{2} q_{2}^{2}\right) .
\end{aligned}
$$




\section{Febriyanti Himmatul Ulya, Syamsuddin Toaha, Kasbawati}

Jika $E>E_{\infty}$, kemudian total pembiayaan dari pemanenan lebih besar daripada total pendapatan dari hasil pemanenan, maka pemanenan akan mengalami kerugian, sehingga tidak dapat dilanjutkan. Jika $E<E_{\infty}$, kemudian pemanenan mengalami keuntungan, maka pemanenan dapat dilanjutkan.

\section{Kontrol Optimal Pemanenan}

Prinsip maksimum pontryagin digunakan untuk menyelesaiakan masalah pemanenan yang optimal. fungsi objektif yang akan dimaksimalkan adalah present value yang didefinisikan sebagai berikut

$$
P V=\int_{0}^{\infty}\left(p_{1} q_{1} x+p_{2} q_{2}-C\right) E e^{-\delta t} d t
$$

dengan $\delta$ meripakan diskonto dengan variable kontrol $E(t)$ dengan batas $0 \leq E \leq E_{\max }, E_{\max }$ adalah batas atas pemanenan atau dapat dtulis $V_{t}\left[0, E_{\max }\right]$. Memaksimalkan $P V$ dapat menggunakan prinsip maksimum prontryagin, maka $P V$ dalam persamaan hamitonian $H\left(x, y, \mu_{1}, \mu_{2}, E\right)$, yaitu:

$$
\begin{aligned}
H= & \left(p_{1} q_{1} x+p_{2} q_{2} y-C\right) E e^{-\delta t}+\mu_{1}\left(r_{1} x-q_{1} E x-b x^{2}-\frac{a_{1} x^{2} y}{x^{2}+k_{1}}\right)+ \\
& \mu_{2}\left(r_{2} y-q_{2} E y-\frac{a_{2} y^{2}}{x+k_{2}}\right)
\end{aligned}
$$

dengan $\mu_{1}, \mu_{2}$ merupakan variable adjoint dan persamaan keadaan sebagai berikut,

$$
\begin{aligned}
& \dot{x}=\frac{d x}{d t}=r_{1} x-q_{1} E x-b x^{2}-\frac{a_{1} x^{2} y}{x^{2}+k_{1}}=0 \\
& \dot{y}=\frac{d y}{d t}=r_{2} y-q_{2} E y-\frac{a_{2} y^{2}}{x+k_{2}}=0
\end{aligned}
$$

persamaan co-state, yaitu:

$$
\begin{aligned}
\dot{\mu_{1}} & =\frac{d \mu_{1}}{d t}=-\frac{\partial H}{\partial x} \\
& =-p_{1} q_{1} E e^{-\delta t}-\mu_{1}\left(r_{1}-q_{1} E-2 b x-\frac{2 a_{1} x y}{x^{2}+k_{1}}+\frac{2 a_{1} x^{3} y}{\left(x^{2}+k_{1}\right)^{2}}\right)+\mu_{2} \frac{a_{2} y^{2}}{\left(x+k_{2}\right)^{2}} \\
\dot{\mu_{2}}= & \frac{d \mu_{2}}{d t}=-\frac{\partial H}{\partial y} \\
& =-p_{2} q_{2} E e^{-\delta t}+\mu_{1} \frac{a_{1} x^{2}}{x^{2}+k_{1}}-\mu_{2}\left(r_{2}-q_{2} E-\frac{2 a_{2} y}{x+k_{2}}\right)
\end{aligned}
$$

Berdasarkan prinsip maksimum pontryagin, kondisi perlu yang dibentuk adalah kondisi stasioner dari $H$, sebagai berikut:

$$
\frac{\partial H}{\partial E}=e^{-\delta t}\left(p_{1} q_{1} x+p_{2} q_{2} y-C\right)-\mu_{1} q_{1} x-\mu_{2} q_{2} y=0
$$

Pada persamaan (20) diperoleh $\left.e^{-\delta t}\left(p_{1} q_{1} x+p_{2} q_{2} y-C\right)-\mu_{1} q_{1} x-\mu_{2} q_{2} y\right)$ yang disebut fungsi switching $\phi(t)$. Ketika dalam $H$, variabel kontrol $E(t)$ muncul secara linier, sehingga $E(t)$ yang optimal tidak dapat ditentukan dengan kondisi $\frac{\partial H}{\partial E}=0$ dan batas maksimal $E_{\text {max }}$ adalah $\infty$, maka masalah tersebut merupakan masalah yang berkaitan dengan penggabungan antara kontrol bang-bang dan kontrol singular. . Kondisi kontrol optimal memenuhi kondisi

$$
\begin{aligned}
& E(t)=E_{\text {max }}=\infty, \text { jika } \phi(t)<0 \\
& E(t)=E_{\text {min }}=0, \text { jika } \phi(t)>0 \\
& E(t)=E^{*}, \text { jika } \phi(t)=0
\end{aligned}
$$




\section{Febriyanti Himmatul Ulya, Syamsuddin Toaha, Kasbawati}

Ketika $E(t)=E^{*}$, maka $\mu_{1} q_{1} x+\mu_{2} q_{2} y=e^{-\delta t}\left(p_{1} q_{1} x+p_{2} q_{2} y-C\right)=e^{-\delta t} \frac{\partial \pi}{\partial E}$. Pada persamaan (21) yang memenuhi kondisi $E(t)=E^{*}$ disebut solusi singular adalah $e^{-\delta t}\left(p_{1} q_{1} x^{*}+p_{2} q_{2} y^{*}-C\right)-$ $\mu_{1} q_{1} x^{*}-\mu_{2} q_{2} y^{*}=0$, diperoleh

$$
\begin{array}{r}
\mu_{1}=\frac{e^{-\delta t}\left(p_{1} q_{1} x^{*}+p_{2} q_{2} y^{*}-C\right)-\mu_{2} q_{2} y^{*}}{q_{1} x^{*}} \\
\mu_{2}=\frac{e^{-\delta t}\left(p_{1} q_{1} x^{*}+p_{2} q_{2} y^{*}-C\right)-\mu_{1} q_{1} x^{*}}{q_{2} y^{*}}
\end{array}
$$

dengan mensubtitusi $\mu_{2}$ dari persamaan (22) ke dalam $\frac{d \mu_{1}}{d t}$ pada persamaan (19), maka dapat ditulis sebagai berikut:

$$
\frac{d \mu_{1}}{d t}-R_{1} \mu_{1}=-R_{2} e^{-\delta t}
$$

dengan $R_{1}=-\left(r_{1}-q_{1} E-2 b x^{*}-\frac{2 a_{1} x^{*} y^{*}}{x^{* 2}+k_{1}}+\frac{2 a_{1} x^{* 3} y^{*}}{\left(x^{* 2}+k_{1}\right)^{2}}+\frac{a_{2} q_{1} x^{*} y^{*}}{q_{2}\left(x^{*}+k_{2}\right)^{2}}\right), R_{2}=p_{1} q_{1} E \frac{a_{2} y^{*}\left(p_{1} q_{1} x^{*}+p_{2} q_{2} y^{*}-C\right)}{q_{2}\left(x^{*}+k_{2}\right)^{2}}$. Solusi dari persamaan (23) adalah $\mu_{1}=\frac{R_{2}}{R_{1}+\delta} e^{-\delta t}+C$. Subtitusi solusi persamaan (23) ke dalam persamaan $\frac{d \mu_{2}}{d t}(19)$, maka diperoleh:

$$
\frac{d \mu_{2}}{d t}-S_{1} \mu_{2}=-S_{2} e^{-\delta t}
$$

dengan $S_{1}=-\left(r_{2}-q_{2} E-\frac{2 a_{2} y^{*}}{x^{*}+k_{2}}\right)$ dan $S_{2}=p_{2} q_{2} E-\frac{a_{1} R_{2} x^{* 2}}{\left(x^{* 2}+k_{1}\right)\left(R_{1}+\delta\right)} e^{-\delta t}$. Solusi dari persamaan (24) adalah $\mu_{2}=\frac{s_{2}}{s_{1}+\delta} e^{-\delta t}+C$ dengan kondisi transversality $\mu_{1}(t)=0$ untuk $t \rightarrow \infty$, sehingga solusi persamaan (23) dan (24) adalah:

$$
\mu_{1}=\frac{R_{2}}{R_{1}+\delta} e^{-\delta t} \text { dan } \mu_{2}=\frac{S_{2}}{S_{1}+\delta} e^{-\delta t}
$$

Bentuk $\mu_{i} e^{\delta t}(i=1,2)$ merepresentasikan shadow price dan solusi persamaan (25) menyatakan bahwa shadow price tetap konstan dalam kesetimbangan optimal dengan memenuhi kondisi $\infty$. Nilai $\mu_{1}$ dan $\mu_{2}$ disubtitusi pada solusi singular saat $t \rightarrow \infty$, sehingga diperoleh

$$
\left(p_{1}-\frac{R_{2}}{R_{1}+\delta}\right) q_{1} x^{*}+\left(p_{2}-\frac{s_{2}}{s_{1}+\delta}\right) q_{2} y^{*}-C=0
$$

Melalui persamaan (4.23) diperoleh pemanenan optimal $E_{\delta}$. Subtitusi persamaan (4.23) pada (4.35) dan $y^{*}=\left(x^{*}+k_{2}\right)\left(\frac{r_{2}-q_{2} E}{a_{2}}\right)$ untuk memperoleh kesetimbangan optimal $\left(x_{\delta}, y_{\delta}\right)$. Kesetimbangan optimal $\left(x_{\delta}, y_{\delta}, E_{\delta}\right)$ dapat berubah-ubah. Perubahan tersebut bergantung pada nilai $\delta$.

Persamaan (4.35) bergantung pada nilai $\delta$, sehingga

$$
\pi(x, y, E)=p_{1} q_{1} x+p_{2} q_{2} y-C=\frac{R_{2} q_{1}}{R_{1}+\delta} x+\frac{S_{2} q_{2}}{S_{1}+\delta} y \rightarrow 0 \text { jika } \delta \rightarrow \infty
$$

Kondisi persamaan (27) menyebabkan keuntungan $\pi\left(x_{\infty}, y_{\infty}, E_{\infty}, t\right)=0$. Persamaan tersebut juga menunjukkan bahwa fungsi keuntungan $\pi$ merupakan fungsi turun, jika diskonto menuju tak berhingga, maka keuntunan akan menuju 0 dan keuntungan akan maksimal jika diskonto menuju 0.

Memaksimumkan present value dapat diperoleh dengan mensubtitusi kesetimbangan optimal $\left(x_{\delta}, y_{\delta}, E_{\delta}\right)$, sehingga diperoleh:

$$
\begin{aligned}
& \int_{0}^{\infty}\left(p_{1} q_{1} x_{\delta}+p_{2} q_{2} y_{\delta}-C\right) E_{\delta} e^{-\delta t} d t=\left(p_{1} q_{1} x_{\delta}+p_{2} q_{2} y_{\delta}-C\right) E_{\delta} \int_{0}^{\infty} e^{-\delta t} d t \\
& =\frac{\left(p_{1} q_{1} x_{\delta}+p_{2} q_{2} y_{\delta}-C\right) E_{\delta}}{\delta}
\end{aligned}
$$




\section{Febriyanti Himmatul Ulya, Syamsuddin Toaha, Kasbawati}

Selanjutnya akan dilakukan simulasi numerik dengan software maple 2016.

\section{Simulasi Numerik}

Nilai parameter berdasarkan dari penelitian-penelitian sebelumnya dan asumsi pada penelitian ini. Nilai parameter yang digunakan dalam simulasi yaitu $r_{1}=0.47, r_{2}=0.2, b=0.75, a_{1}=1.0$, $a_{2}=0.85, k_{1}=200, k_{2}=10, p_{1}=0.26, p_{2}=0.32, q_{1}=0.4, q_{2}=0.2, C=0.18$.

Titik kesetimbangan pada model leslie-gower fungsi respon holling III tanpa pemanenan diperoleh yaitu $T_{2}(5.5203,2.9215)$ dengan matriks Jacobian $J\left(T_{2}\right)=\left(\begin{array}{cc}-0.4552 & -0.1058 \\ 0.0301 & -0.1600\end{array}\right)$. Persamaan karakteristik dari matriks $J\left(T_{2}\right)$ adalah $\lambda^{2}+0.1718 \lambda+0.0012$. Nilai eigen yang diperoleh dari persamaan karakteristik tersebut adalah $\lambda_{1}=-0.1645$ dan $\lambda_{2}=-0.0073$, sehingga titik kesetimbangan $T_{2}$ stabil asimtotik Trayektori di sekitar titik kesetimbangan $T_{2}$ sebagai berikut:

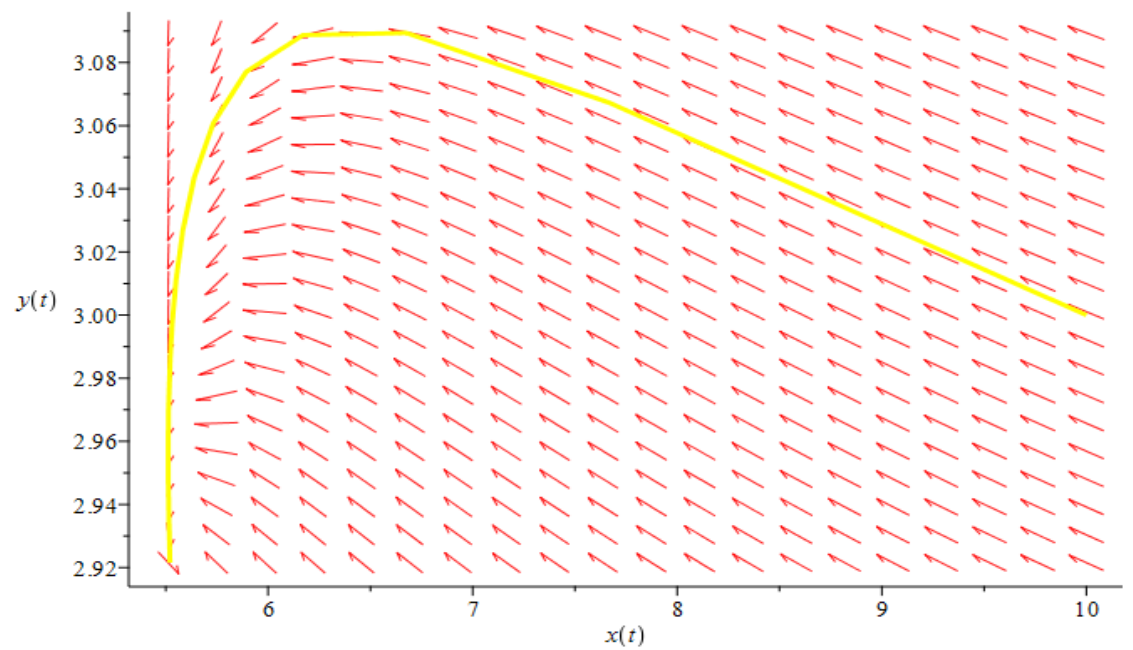

Gambar 1. Trayektori di sekitar titik kesetimbangan $T_{2}$

Titik kesetimbangan pada model leslie-gower fungsi respon holling III dengan pemanenan diperoleh yaitu dengan membebaskan nilai parameter $E$ adalah $H_{2}\left(x_{4}^{*}, y_{4}^{*}\right)$ dimana, $x_{4}^{*}=0.0078\left(-16660800 E^{2}-865635960 E+981026791-1728000 E^{3}+425\right.$ $\left(20044800000 E^{4}+187880960000 E^{3}+3810859104000 E^{2}-11470917240000 E+\right.$ $\left.13965165150000)^{\frac{1}{2}}\right)^{\frac{1}{3}}-\left(127.5\left(-5.6938 E+71.3442-0.8858 E^{2}\right)\right) /\left(-16660800 E^{2}-\right.$ $865635960 E+981026791-1728000 E^{3}+425\left(20044800000 E^{4}+187880960000 E^{3}+\right.$ $\left.\left.3810859104000 E^{2}-11470917240000 E+13965165150000\right)^{\frac{1}{2}}\right)^{\frac{1}{3}}-0.9412 E+1.4196$ dan $y_{4}^{*}=1.1765\left(0.0078\left(-16660800 E^{2}-865635960 E+981026791-1728000 E^{3}+\right.\right.$ $425\left(20044800000 E^{4}+187880960000 E^{3}+3810859104000 E^{2}-11470917240000 E+\right.$ $\left.13965165150000)^{\frac{1}{2}}\right)^{\frac{1}{3}}-\left(127.5\left(-5.6938 E+71.3442-0.8858 E^{2}\right)\right) /\left(-16660800 E^{2}-\right.$ $865635960 E+981026791-1728000 E^{3}+425\left(20044800000 E^{4}+187880960000 E^{3}+\right.$ $\left.\left.\left.3810859104000 E^{2}-11470917240000 E+13965165150000\right)^{\frac{1}{2}}\right)^{\frac{1}{3}}-0.9412 E+11.4196\right)$ $(0.2 E+0.16)$ 


\section{Febriyanti Himmatul Ulya, Syamsuddin Toaha, Kasbawati}

Jika $x_{4}^{*}$ dan $y_{4}^{*}$ disubstitusi ke persamaan (10), diperoleh fungsi keuntungan sebagai berikut:

$\pi=0.0006\left(-16660800 E^{2}-865635960 E+9.81026791-1.728000 E^{3}+\right.$

$425\left(20044800000 E^{4}+187880960000 E^{3}+3810859104000 E^{2}-11470917240000 E+\right.$

$\left.13965165150000)^{\frac{1}{2}}\right)^{\frac{1}{3}}-\left(10.2\left(-5.6938 E+71.3442-0.8858 E^{2}\right)\right) /\left(-16660800 E^{2}-\right.$

$865635960 E+9.81026791-1.728000 E^{3}+425\left(20044800000 E^{4}+187880960000 E^{3}\right.$

$\left.\left.+3810859104000 E^{2}-11470917240000 E+13965165150000\right)^{\frac{1}{2}}\right)^{\frac{1}{3}}-0.0753 E-0.0664$

$+0.0611\left(0.0078\left(\left(-16660800 E^{2}-865635960 E+9.81026791-1.728000 E^{3}+\right.\right.\right.$

$425\left(20044800000 E^{4}+187880960000 E^{3}+3810859104000 E^{2}-11470917240000 E+\right.$

$\left.\left.13965165150000)^{\frac{1}{2}}\right)^{\frac{1}{3}}-127.5\left(-5.6938 E+71.3442-0.8858 E^{2}\right)\right) /\left(\left(-16660800 E^{2}-\right.\right.$

$865635960+9.81026791-1.728000 E^{3}+425\left(20044800000 E^{4}+187880960000 E^{3}+\right.$

$\left.\left.3810859104000 E^{2}-11470917240000 E+13965165150000\right)^{\frac{1}{2}}\right)^{\frac{1}{3}}-0.9412 E+$

$11.4196)(0.2 E+0.16)$

Kesetimbangan bionomik terjadi ketika total pendapatan hasil penjualan pemanenan sama dengan pembiayaan dari pemanenan atau fungsi keuntungan sama dengan 0 , sehingga dari diperoleh nilai $E=0.7637$.

Nilai $E=0.7636$ yang diperoleh disubtitusi ke titik kesetimbangan $H_{2}$, sehingga diperoleh titik kesetimbangan $H_{2}(2.1822,0.1043)$ dengan matriks Jacobian $J\left(H_{2}\right)=\left(\begin{array}{cc}-0.1645 & -0.0186 \\ 0.0001 & -0.0073\end{array}\right)$. Persamaan karakteristik dari matriks $J\left(H_{2}\right)$ adalah $\lambda^{2}+0.1718 \lambda+0.0012$. Nilai eigen yang diperoleh dari persamaan karakteristik tersebut adalah $\lambda_{1}=-0.1645$ dan $\lambda_{2}=-0.0073$, sehingga titik kesetimbangan $\mathrm{H}_{2}$ stabil asimtotik. Trayektori di sekitar titik kesetimbangan $\mathrm{H}_{2}$ sebagai berikut:

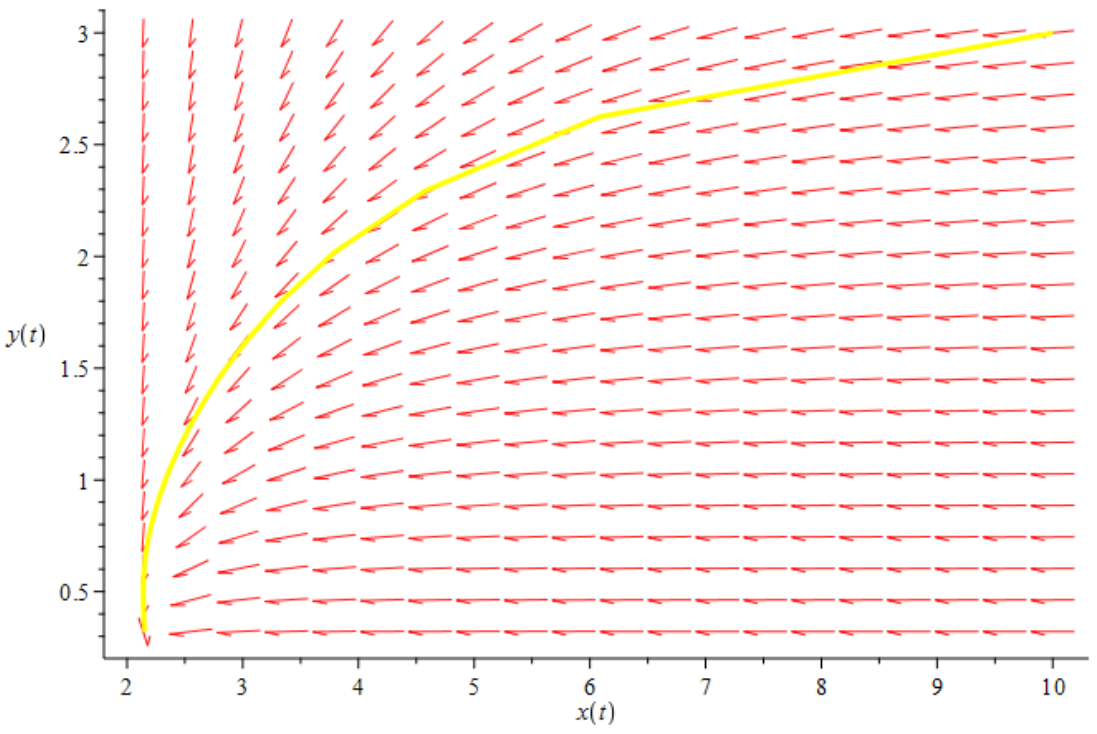

Gambar 2. Trayektori di sekitar titik kesetimbangan $\mathrm{H}_{2}$

Pada model (4.7), kesetimbangan bionomik terjadi ketika pemanenan yang dilakukan dengan batas pemanenan untuk populasi predator dan prey $P_{\infty}\left(x_{\infty} . y_{\infty}, E_{\infty}\right)$ yaitu $P_{\infty}(2.1822,0.1043,0.7637)$. 


\section{Febriyanti Himmatul Ulya, Syamsuddin Toaha, Kasbawati}

Pada kontrol optimal pemanenan, nilai $\mu_{1}$ dan $\mu_{2}$ pada kontrol optimal, yaitu:

$\left.\mu_{1}=\left(0.08 E x^{2}+1.6 E x+8 E-0.34 x y-0.221 y^{2}+0.765 y\right) e^{\delta t}\right)\left(x^{2}+200\right)^{2} /\left(0.15 x^{7}+\right.$

$(2.536+0.4 E) x^{6}+(65.72+8 E-1.7 y) x^{5}+(968 .+200 E) x^{4}+(-360 y+3200 E+8288) x^{3}+$

$\left.(6400 y+32000 E+82880) x^{2}+(228800-36000 y+320000 E) x+1600000 E-1856000\right)$ dan

$\mu_{2}=\left(54.4 x^{3} y-96512 E+0.0679 E x^{6}+2.1374 E x^{5}+0.272 x^{5} y+31.136 E x^{4}+174.976 E x^{3}-\right.$

$122.4 x^{2} y+3029.76 E x^{2}+11897.6 E x-18.72 E x^{3} y-1872 E x y-0.0884 E x^{5} y+332.8 E x^{2} y-$

$0.612 x^{4} y+83200 E^{2}+0.0078 x^{7}+0.0208 E^{2} x^{6}+0.416 E^{2} x^{5}+10.4 E^{2} x^{4}+166.4 E^{2} x^{3}+$

$\left.\left.1664 E^{2} x^{2}+16640 E^{2} x+35.36 x^{2} y^{2}+0.1768 x^{4} y^{2}\right) e^{\delta t}\right)(x+10) /((228800 x-36000 x y-$

$360 x^{3} y+1600000 E-1856000+2.536 x^{6}+65.72 x^{5}+968 x^{4}+0.15 x^{7}+0.4 E x^{6}+8 E x^{5}-$

$1.7 x^{5} y+200 E x^{4}+3200 E x^{3}+6400 x^{2} y+32000 E x^{2}+320000 E x+82880 x^{2}+$

$\left.\left.8288 x^{3}\right)(-0.154 x-1.54+0.2 E x+2 E+1.7 y)\right)$

Nilai $\mu_{1}$ dan $\mu_{2}$ disubtitusi ke dalam persamaan (26) dan mengeliminasi dengan persamaan (14) dan mengambil nilai $\delta=0.006$, maka diperoleh kesetimbangan optimal dengan pemanenan yang dilkukan pada populasi predator dan prey $\left(x_{\delta}, y_{\delta}, E_{\delta}\right)$ yaitu $(2.25,4.6411,0.6513)$, sehingga dengan mensubtitusi kesetimbangan optimal ke dalam persamaan (28) diperoleh nilai present value adalah 26.1963.

\section{DAFTAR PUSTAKA}

[1] Ashine, Ahmed Buseri dan Dawit Melese Gebru, 2017. Mathematical Modeling of a Predator-Prey Model with Modified Leslie-Gower and Holling-Type II Schemes. Mathematics and Decision Sciences. 17: 20-40.

[2] Ávila-Vales, Eric, dkk. 2017. Bifurcations of a Leslie-Gower Predator-Prey Model with Holling Type III functional Response and Michaelis-Menten Prey Harvesting. https://arxiv.org/pdf/1711.08081.pdf.

[3] Barnett, S., 1971. A New Formulation of The Theorems of Hurwitz, Routh and Sturm. J. Inst. Maths Applics. 8: 240-250.

[4] Berryman, Alan. A. 1992. The Origins and Evolution of Predator-Prey Theory. Ecology. Amerika. 73: $1530-1535$

[5] Boyce, William E dan Richard DiPrima. 2012. Elementary Differential Equations and Boundary Value Problems. Wiley \& Sons: Amerika.

[6] Chen, Fengde, dkk. 2017. Dynamic Behaviors Nonautonomous Modified Leslie-Gower PredatorPrey Model with Holling Type III Schemes and a Prey Refuge. Journal of Mathematics and Computer Science. 17: 266-277Clark, Colin W. 2006. The Worldwide Crisis in Fisheris. Cambridge University Press: Inggris.

[7] Didiharyono., 2016. Analisis Kestabilan dan Keuntungan Maksimum Model Predator-Prey Fungsi Respon Tipe Holling III dengan Usaha Pemanenan. Masagena Jurnal. 11: 314-326.

[8] Huang, Jicai, Shigui Ruan dan Jing Song., 2014. Bifurcations in a Predator-Prey System of Leslie Type With Generalized Holling Type III functional response. Journal of Differential Equations. http://dx.doi.org/10.1016/j.jde.2014.04.024. 


\section{Febriyanti Himmatul Ulya, Syamsuddin Toaha, Kasbawati}

[9] Kempf, Alexander., 2008. Predator-Prey Overlap Induced Holling Type III Functional Response in The North Sea Fish Assemblage . Marine Ecology Progress Series. 367: 295-308.

[10] Keshet, Leah Edelstain. 2005. Mathematical Models in Biology. SIAM: Amerika.

[11] Khalil, Hassan K., 2002. Nonlinear Systems Third Edition. Prentice Hall: Amerika.

[12] Lenhart, Suzanne dan John T. Workman., 2007. Optimal Control Applied and Biological Models. CRC Press: New York.

[13] Leslie, P.H. dan J. C. Gower. 1960. The Properties of a Stochastic Model for The Predator-Prey Type of Interaction Between Two Species. Biometrika. 47: 219-234.

[14] Maziun, Nur Aina, dkk., 2010. Analisis Stabilitas Lokal dan Kontrol Optimal Pada Terapi Obat Dalam Pengobatan Kanker. ITS Library. http://digilib.its.ac.id/ITS-Undergraduate$3100010041711 / 13408$.

[15] Naidu, D. S., 2002. Optimal Control Systems. CRC Presses LLC: Amerika.

[16] Prastiwi, Lusiana dan Subiono. Aplikasi Prinsip Maksimum Pontryagin Pada Model Bioekonomi Prey-Predator dengan Waktu Tunda. Prosiding Seminar FMIPA UNS. Surabaya, 24 Januari 2012.

[17] Shaikh, Absos Ali, dkk. Study of LG Holling Type III Predator-Prey Model with Diseas in Predator. Journal of Mathematics and Computing. 1-21.

[18] Sharma, Anuj. K, dkk., 2014. Dynamical Analysis of a Harvesting Model of PhytoplanktonZooplankton Interaction. International Journal of Mathematical, Computational, Physical, Electrical and Computer Engineering. 8: 1013-1018.

[19] Sinclair, A. R. E, dkk. 1998. Prediciting Effect of Predation of Conservation of Endangered Prey. Conservation Biology. 12: 564-575.

[20] Taha, Hamdy. A. 2007., Operations Research: An Introduction Eight Edition. Pearson Education: Amerika.

[21] Thomas, George B., 2014. Calculus Early Transcendentals Thirteenth Edition. Pearson Education: Amerika.

[22] Wiggins, Stephen., 2003. Introduction to Applied Nonlinear Dynamical Systems and Chaos. Springer: Amerika.

[23] Yang, Wensheng dan Yongqing Li., 2013. Dynamics of a Diffusive Predator-Prey Model with Modified Leslie- Gowwer and Hollig Type III Scjemes. Computers, Mathematics and Applications. 65: 1727-1737.

[24] Yue, Qin. ,2016. Dynamics of Modified Leslie-Gower Predator-Prey Model with Holling Type II Schemes and Prey Refuge. Springer Plus. 5: 1-12.

[25] Toaha, S dan M I Azis., 2018. Stability and Optimal Harvesting of Modified Leslie-Gower PredatorPrey Model. Journal of Physics. 979: 1-9. 